\title{
Communicative Strategies of Professional Development of a TV and Radio Journalist: Psychotypology and Social Model
}

\author{
Oles Goian ${ }^{1}$ \\ Vita Goian ${ }^{1}$ \\ Tetiana Biletska ${ }^{1}$ \\ Anastasiia Bessarab ${ }^{2}$ \\ Natalia Zykun ${ }^{3}$ \\ ${ }^{1}$ Taras Shevchenko National University of Kyiv, Ukraine \\ ${ }^{2}$ Municipal Institution of Higher Education \\ "Khortytsia National Educational Rehabilitation Academy" of \\ Zaporizhzhia Regional Council, Ukraine \\ ${ }^{3}$ University of State Fiscal Service of Ukraine, Ukraine
}

DOI: https://doi.org/10.36941/ajis-2020-0093

\section{Abstract}

The whole world undergoes significant changes in communication, television and radio. Therefore, journalism education also alters. Television companies and radio stations hire former students, who already perceive the development of modern media in a different way, and thus try to communicate differently and influence large audiences. It is applied to all societies and countries developing their own media and caring about the future of television and radio industry. Such a new complex problem on communication via television and radio is caused primarily by the changes of information technology and communicative strategies in the field of media, online educational techniques in world schools of journalism, and is now being discussed by theorists and practitioners of journalism on various media platforms or global forums. The purpose of the article, that is based on the long-term research of scientists at Taras Shevchenko National University of Kyiv, is to set and prove the hypothesis about the future of television and radio broadcasting, in particular, those who will come to work on television or are already working, combining studying with practical activity. Within the period of 2012-2019 the authors of the article interviewed 76o students of the Institute of Journalism, Taras Shevchenko National University of Kyiv, on the basis of their statements about the choice of specialization, and collected the data on their attitude to modern media, including television and radio. As a result of the research, the authors have developed the psychotypology of students who will work for television and radio companies in Ukraine, and form the public opinion on social, sociocultural and political processes in the country. Consequently, this psychotypology (classics, jazzmen, rockers and conformists) can be used in schools of journalism in other countries as a technological approach to model the matrices of the educational process for training the TV and radio journalists.

Keywords: television, radio, journalism education, online media technology, communicative strategies, social setting

\section{Introduction}

Journalism education in Ukraine is represented in various journalism schools in different universities. These are the faculties, institutes and departments that prepare journalists for the media with 
Bachelor and Master Degrees. As of 2019 in Ukraine, such educational activities were conducted in 39 universities. The Institute of Journalism, at Taras Shevchenko National University of Kyiv, has been on the media education market for over 6o years: it was created as a journalism faculty in 1953 and 40 years later it was reorganized into the Institute of Journalism. Since then it has been one of the most prestigious centres for journalism education and science. Since 1971, it has been training professional journalists in the field of television and radio broadcasting, and in 2012 it also provided specialists in audiovisual arts and production. What are our students like? What interests them in the future profession? What are the reasons of choosing this particular specialization? These questions are raised by the authors of the article in order to respond to students' current requests and adjust the training courses, update the discipline programs, and ultimately predict what mass media potential will be in the coming years. At present, almost $80 \%$ of future broadcasters admit that they do not "watch television or listen to the radio" at all, as they "use the Internet for these purposes". This is one of the main discoveries based on the research conducted by the authors of the article in the Institute of Journalism, Taras Shevchenko National University of Kyiv, and other higher educational institutions where journalism is taught within the period of 2012-2019. The studies mainly concerned the preparation of journalists for television and radio broadcasting and aimed at providing the answer to the question of the expediency of teaching theoretical courses, in particular, on the issues of new media communications in broadcasting and journalism, as well as the increase in the number of educational television and radio online projects as a practical part of the disciplines taught.

For this purpose, in 2010, in the Institute of Journalism, Taras Shevchenko National University of Kyiv, a convergent media platform of students' projects "Campus Radio Ukraine / Student-TV" was created, which became the basis for the practical training of TV and radio journalists. This student media platform, along with more than 90 other student media projects of various Ukrainian universities, represent the segment of student television broadcasting online. The main conceptual aspects of functioning the student media, in particular, the experience of "Campus Radio Ukraine / Student-TV" presented in the research of the authors of this article (O.Goian \& V.Goian, 2013), provide the examples of the successful implementation of various media initiatives - starting with the creation of educational television and radio programs online, testing different genres and formats in educational studios and newsrooms, conducting professional trainings and workshops and finishing with scientific research in the media industry. The student media help better understand the content of training courses, put into practice the current journalistic standards, methods and technologies, so as not only to get high grades during the exams, but also to have more chances to succeed in the profession. Moreover, this type of student media projects demonstrates the technical capabilities of universities in organizing open media space for creativity and research. However, first and foremost, this unusual approach of student media encourages students' self-determination, makes them socialize and create professional communities.

\section{Literature Review}

The role of student broadcasting in shaping the media landscape of different countries is constantly discussed by theorists and practitioners (R. McCormick, 1985), particularly in those countries where the student movement plays a significant role in political events, the formation of civil society and public opinion. The main messages of scientific publications and public speeches on the subject concerned the conformity of educational programs in broadcast journalism with modern requirements in professional broadcasting. As scientists state, another important component to consider today is how well information education technologies in various journalism schools are responsive to online broadcasting (YouTube, Netflix, etc.), social media or internet services (IPTV, OTT, video on demand, etc.), and how the students who choose the profession of journalist are mentally prepared to view television and radio broadcasting as a competitive labor market or modern business sphere, and whether they can apply their knowledge and skills accordingly.

Online TV viewing and online radio listening, using predominantly smartphones, is 
subconsciously associated with technological capabilities among the users, saying "first there must be the internet and then the content". Therefore, online technologies, which are sometimes mistakenly called "new media", are the most important means in modern communication, and the rest, namely linear television broadcasting, are classified as "outdated, routine and unpromising." In general, this viewpoint leads to the change of concepts: the production of TV and radio content is substituted by online distribution, so students generally believe that television and radio are so-called "traditional media" and the Internet is "new media", which let these "rare" media fade into the background (according to the legislation of Ukraine, 2020). Such beliefs are predominantly based on the emotional factors, stereotypes and superficiality rather than acquired knowledge, and consequently influence the students' choice of professional specialization, resulting in the erosion of basic criteria of the broadcasting profession, which is now largely targeted at blogging. This affects the quality of the audiovisual product available on the online platforms of TV and radio companies.

Let us turn to research that may be useful for specialists. Among the systemic concepts identified by the researchers, one should consider the work by Theodor V. Adorno "Favorites: Sociology of Music" (Theodore V. Adorno, 1998), which states that society is a group of people who "can either listen to music, or not". The scientist points out that "it is the objective structural features of music that determine the reactions of the listener." This approach can be reflected in people's perception of television, as the emotional factor, which becomes the basis of the audience's response to music, is characteristic of watching television programs by the same audience. Especially it concerns the student youth who are planning to work in broadcasting, and therefore create an audiovisual product, which, in turn, should form and retain the target audience and ensure the commercial success for both broadcasters and authors of TV and radio programs.

The broadcasting market around the world is also similar to the music market as it focuses on the audience which tend to migrate and whose tastes and preferences change due to fashionable trends, sociocultural circumstances, and mental characteristics. It is worth mentioning here the social setting, which is considered "the main component of consciousness that regulates our behavior towards something or someone" (Roshchin S.K., 1989). In fact, the components of a social setting are the following: evaluative-emotional, which creates the system of personality characteristics in relation to a specific audience in society; cognitive, which aims to gather certain ideas and knowledge about the target audience in society; and motivating, which determines the desire to act in certain circumstances in accordance with the knowledge, ideas and emotions acquired.

Watching TV or listening to the radio is also, to a certain extent, a social setting that is oriented to the lifestyle of the audience, which fits into the formula of "living one life with an audience, adopting its daily routine, forming its own image in accordance with the image of the target audience" (Sukhareva V., 2003). We can apply this model to the assessment of new realities of perception by students, namely future journalists of modern television and radio broadcasting.

\section{Methods}

The authors of this study (within the period of 2012-2019) have accumulated and studied the data obtained from questioning the students (future journalists) during the seminars and practical lessons and analysing their 760 written statements, annually submitted to the departments, regarding the choice of a certain educational program and specialization (television, radio or the internet). One of the goals of such a study was to identify the likely pattern of students' choice of a particular specialization and the likelihood of the change in the professional environment. The authors were interested in the mental and educational level of students, who, choosing their specialization, also chose the future sphere of professional journalistic activity.

The data obtained through the use of survey and content analysis methods can be considered representable for Ukrainian journalism schools and recommended for journalism schools in other countries that prepare professionals in the field of television and radio broadcasting.

Thus, the results of the professional selection of student journalists to television, radio or 
internet groups within 2012-2019 period showed a tendency to increase the number of students who expressed a desire to study online specialization. Most respondents explained their choice with the opportunity to study current disciplines and be able to acquire knowledge and skills that will provide employment benefits. The number of applications submitted for TV and radio specializations within the investigated period decreased accordingly.

3.1 Using the method of content analysis, the annual number of student applications was analyzed (on average, 100-120 students of the 2nd year chose the specialization according to their curricula), which led to certain conclusions

A questionnaire method was used to identify the psychotype of students who choose a particular journalism specialization.

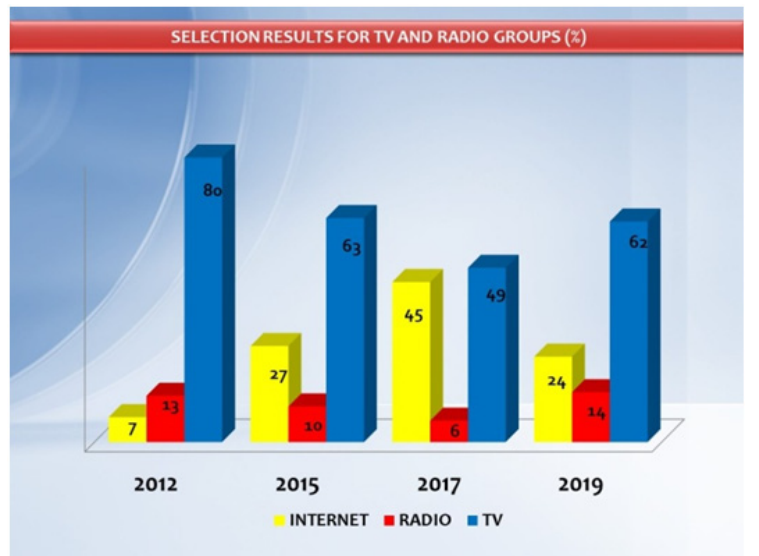

3.2 Using the survey method, in November 2019, a professional survey of students was conducted on the selected specialization (96 paper questionnaires). It contained the following basic questions:

1. What technologies do you use to watch TV and listen to the radio: terrestrial (digital) broadcasting, satellite, cable, online broadcasting?

2. How much time (in hours) per week do you watch television or listen to the radio?

3. Do you usually listen to the radio in the background or purposefully?

4. What music do you enjoy most: classical, rock, jazz, none of the above?

5. Is modern journalism more of an "individual" or "collective" profession?

6. If you choose a speciality in television or radio broadcasting, does it mean that you plan to work for television or radio companies after completing your studies? Yes or no?

\section{Results and Discussion}

The data received on the basis of the questionnaire have allowed the researchers to record the following results:

1. Terrestrial (digital) broadcasting - 32\%, satellite broadcasting - $19 \%$, cable broadcasting $36 \%$, online broadcasting $-13 \%$;

2. 6 hours (on average);

3. Background - $78 \%$, purposefully - $22 \%$

4. Classical $-16 \%$, rock $-38 \%$, jazz $-18 \%$, none of the above $-28 \%$

5. Individual - $45 \%$, collective - $55 \%$; 
6. Yes $-73 \%$, no $-27 \%$.

Consequently, the results of the survey and content analysis, along with the emotional and objective factors, supported by the admirers of the sociology of music, which are now being projected on various aspects of perception of reality, made it possible to outline the psychotypes of students' perception of modern broadcasting. It is worth noting that the structure of typology is based on three basic functions of television - information, entertainment and education, and accordingly the formation of the target audience for the needs and interests. This should include such factors as "have fun or relax", "receive more information you need", "gain more knowledge" or "find a job on television or radio, namely, television and radio is the main business area for the future". Taking into account the already stated social settings of watching television and listening to the radio and the results of the research of the student audience, as well as referring to the achievements in the field of the already mentioned theory of sociology of music, we offer a typology of users of modern broadcasting among the students of journalism schools. Using the data on the psychotypes of broadcasting users among student journalists, the social settings of a certain audience regarding the type of television channel are created. Such information is useful for developing the concept of broadcasting, further program planning and media management. Moreover, it will be essential for updating curricula for future journalists in specialized educational institutions. Yet, the top broadcasting companies of different formats that have data on the target audience should be the basic media for conducting the research.

According to the typology of perception of contemporary television and radio broadcasting by students, in particular student journalists, we form four psychotypes that reflect the main four groups of the relationship between musical taste and personality type (Audiomania, 2018).

4.1

"Classics"

The first type, "Classics", are the students who perceive the development of broadcasting at the level of statics, i.e., in their beliefs and tastes, they consider it unchanged. The name "Classics" is chosen not because students of this type tend to watch television or listen to the radio using a terrestrial, cable or satellite television or radio, although they have all the capabilities to watch and listen online. "Classics" serve as a stable classical paradigm which is characteristic of basic theory of television and radio broadcasting (genres, types, journalistic professions), and is highly appreciated by university lecturers during examinations. However, the fact is that "Classics" do not often notice the prospects of modern television and radio broadcasting and are not quite ready to practise qualitatively and adapt classical television to current media. The latter needs both new preferences, tastes, emotions, feelings and the knowledge of new broadcasting technologies.

"Classics" are oriented in the theory of broadcasting and are prone to analytical thinking and self-improvement, but their confidence is beyond the textbooks and manuals. They are usually introverts and very reserved. Perhaps the lack of communication does not allow them to unleash the full potential and demonstrate unusual knowledge in practice.

"Classics" are aware of broadcasting at the level of "I read and heard about everything, that's why I know everything". They can logically structure and index any program they watched based on, for example, previous minor experience working with broadcasters as a trainee or freelance correspondent. Such students identify classical types and formats of television and radio stations that are structurally and logically related in the profession. As a rule, they continue the family dynasties in the field of broadcasting, are able to talk about the peculiarities of a format or technology of creating a particular type of television program, but they can rarely apply their classical academic knowledge to practice.

The characteristic of this type is the academic knowledge that is essential to have authority in society, constantly improve themselves and develop their skills. "Classics" can show their knowledge either perfectly or satisfactorily, completely or partially. These students demonstrate that they know the most, so they strive to combine their awareness and knowledge in theory with the basics of the 
disciplines. Such knowledge on seminars can be evaluated perfectly, but the practical realization of their competencies may not always be adequate.

There are few "Classics". They seek academic education and do not give up tackling challenges. However, they are not leaders in the creative approach preparing for television and radio programs. They are ready to work with certain blocks, clichés, standard schemes, but they are not able to offer something new and original, which is always crucial on the competitive TV and radio market.

4.2

\section{"Jazzmen"}

The second type is a "student-jazzman" who perceives broadcasting subconsciously on a sensual level as a vital necessity or as a form of existence. If "Classics" perceive television broadcasting mindfully, "Jazzmen" are guided by their feelings.

Jazz as a music style is characterized by originality, creative thinking, rejection of standard rules, norms, templates, restrictions, etc. Therefore, "Jazzmen" are peculiar for their volatility, which is visible at the highest emotional levels, which are sometimes in polar positions: "I like / dislike TV and radio". Moreover, when it is necessary to explain why you like it or not, one should not expect to receive the exact answer. Unlike "Classics", "Jazzmen's" emotions are based on feelings and instincts, so the profession of journalist is formed mainly not in the process of socialization, but in the course of self-identification, involvement of subconsciousness, manifestation of genetic and hereditary traits.

"Jazzmen" are among the first to master audio and video editing, work with a camera or microphone. They are enthusiastic about technological innovations in TV and radio broadcasting and are able to adapt quickly to new online communications. For these students, online television and radio broadcasting is a space of freedom and a means of assertion, especially when it is possible to get a quick feedback from the audience on social networks about their professional success. However, the ability of self-absorption and improvisation can cause the battle of opposites to fail, for instance, listening to lumpen Russian chanson. Sensitive communication and exquisite openness in the style of "jazz compositions" will go from broadcasting to nowhere.

Students of this type are creators. They come up with a variety of their own ideas and new formats of television and radio programs, and, most importantly, are able to implement them successfully. Their knowledge of broadcasting remains at the level of individual feelings: "something in the soul." They may not be fully aware of the theory of television and radio broadcasting and take exams in the style "if my luck changes". This is not the main thing for them. Most important are inspiration and creativity. That is why "Jazzmen" view the future profession as a platform for expression of freedom and creative self-realization.

"Jazzmen"-students make up the vast majority of those who are in constant contact with television and radio companies, trying to be creative at work. The representatives of this type enthusiastically share their impressions of the practical sphere and the future profession. It is desirable for every TV and radio company to have such employees who are mobile and active, eager to succeed and open to everything new. They are able to convey emotions to their listeners and viewers and keep contact with the audience. But are "Jazzmen" truly sociable and sincere with likeminded people while being restraint with their opponents? In fact, a "Jazzman" is like a man band, a single talent, an individuality for whom corporate strategy and teamwork are pragmatism, clarity and not a copyright improvisation.

The "Jazzmen's" creative immediacy and sincerity are limited by a variety of factors: bureaucratic, managerial and administrative ones, sponsorship obligations, editorial comments, fights for ratings and "ungrateful or primitive" audience. Under such pressure, "Jazzmen" can even abandon their incredible ideas in broadcasting and consider other media spheres more suitable for creative endeavours.

In general, the instinctive perception of the creative profession, in particular, a television and radio journalist, is characteristic of an emotionally open-minded type of people who can burst into crying while editing a program with Mozart's Requiem. Therefore, when choosing a particular 
creative profession, one should rely not only on the rational but also deal with the emotional component, aligning one's ambitions with the reality, and one's creative beliefs with the varied requests of the target audience. All in all, understanding the psychotypes of student journalists is useful for developing a more effective organization of the educational process than the traditional system of lectures and seminars. For example, using the principle of creative workshops to teach "Jazzmen" should be combined with the increasing number of academic hours for the practical part of the courses.

\section{3}

\section{"Rockers"}

The third type, "Rocker"-student, is very similar to the "Classic"-student in terms of the categorical perception of many standards in broadcasting. However, "Rockers" are "rebels" whose lifestyle is based on the formula "television and I" or "radio and I" and, what is most importantly, they successfully prove it with their theoretical studying and practical achievements.

"Rockers" trace some analogy between the formation of conceptually distinct components of modern culture, electronic media, television and radio and rock as a musical stream. One can agree with such considerations as rock music has played a significant role in the process of shaping contemporary music culture. However, "Rockers" are not orthodox. They can perceive rock as "Classics", thoroughly upholding the origins, without ignoring the role of rock in isolating other musical currents, which popularize it, for example, jazz rock, pop rock, etc. "Rockers" understand the primary role of television and radio broadcasting in the appearance of audio and video content on websites, blogs, podcasts, etc. Rock, based on artists' ambitions, musicians' charisma and national musical experience, has long paved the way for originality, individuality and uniqueness, in particular, due to one of its characteristic features - improvisation.

Improvisation is not only the ability to create arbitrary compositions or designs, it is the artist's ability to express their thoughts, feelings and impressions. So which way of creative self-realization is most appropriate for modern students of this psychotype? Is it unpredictability, the production of something new or skilfully interpreted? "Rockers" need to be aware that mass media audience cannot be a connoisseur of improvisation. So, they will have to form their own, niche audience, according to their vision and understanding of the meaning of creativity.

Rock put a lot of effort to make its way into the post-Soviet space since the so-called "Soviet music" was addressed mainly to the masses, not to personal tastes, which, after all, was embedded in the very psychology of that society. Individualism, as a form of self-awareness of the individual, was perceived within a party context. Any "free, rebellious" interpretation of reality was considered "outlaw", especially when it came to the Ukrainian society, which suffered grievous losses: famine, political persecution of intellectuals, consistent destruction of the "bloom of the nation", dissidence, forced emigration, destruction and restoration of statehood (Lyzanchuk V.V., 1997). Television and radio broadcasting in the former Soviet empire received the audience that, on the one hand, was frightened and, on the other hand, could not express their own opinion, independently evaluate facts, events or phenomena, i.e., reveal individuality and stand out of "collective" interests. It significantly affected the quality of broadcasting, limited the typological and genre range of programs, technological and creative frameworks of broadcasting, namely, live broadcasting, ways of attracting audience and completely standardized work of journalists. That is why "Rockers" have been and still remain demanded in today's TV and radio broadcasting. "Rockers" are exclusive personnel in the TV and radio companies with their personalities, disparity and difference from others. It is also a format, profile or technological specialization.

A kind of password to rock, classical music or jazz has always belonged to non-conformism (Tkachuk T, 2004), the basic principles of which are typical of student journalists mentioned above. Somewhat aloof there are students who choose television and radio specialization, "because it's fashionable". This is the fourth type - student-conformist. 


\section{4 "Conformists"}

"Conformists" are categorical enough in their judgments. They perceive television and radio as a sort of "parallel world" that can be cognized remotely, and are convinced that the mere fact of being on student lists confirms their membership in the journalist community. And this determines their leadership in any youth company. They think they are better at television and radio than other people. And although such beliefs are groundless, these students often try to persuade their opponents to do the opposite by operating in the categories "like - dislike". They can also tell the colleagues or friends how easy it is to create television or radio programs. However, when they start working with the broadcasting material, it turns out that they are scared of the camera, can't work with the microphone and even unable to produce simple audio or video information. "Conformists" choose the specialization of broadcasting mostly in order to boast about their "privileged" status. They are ready to change the specialization at the first failure, or when they realize that in this sphere they will have to make more efforts, neglecting their own time, than they expected. "Conformists" will not become "patriots" of broadcasting, will not delve into its history and will not worry about the future. They somehow master the basic concepts of broadcasting, but understand the competitive advantages of television and radio.

This type of student is somewhat similar to large target media audiences who identify television and radio as an entertainment area. They turn on television and radio only to improve their mood. Actually, broadcasting works, taking into account the audience's requests and market expediency. Today's audiovisual media is the entertainment industry. And it is not surprising, since broadcasting performs one of its leading functions (Karpenko V., 2002). It seems easy to work with viewers and listeners focused on entertainment. They are interested in games or quizzes with simple questions, themed entertainment programs (fashion, lifestyle, social events, horoscopes, etc.), even the motivational format (useful tips, advice or cautions) and, of course, different kinds of music. At the same time, the entertainer is a paradoxical target for the producers of the show: the TV viewers and radio listeners want to have fun, but remain passive observers (they ignore interactive communication, calls or comments online), they take broadcasting for granted.

Conformism (from Latin conformis - similar, corresponding) is explained as a passive acceptance of customary patterns of behavior, recognition of existing standards and rules, imitation of idols and adaptability to circumstances (Dictionary of Foreign Languages, 2000). It is the perception of the surrounding reality that is projected on the perception of broadcasting, and vice versa. It is revealed in indifference and infantry to what is happening around and what is on the radio and TV. This is a collective portrait of a "Soviet collectivist", a person of "the time" when the principle of "being as everyone" or "initiative is punished" was interpreted as "being invisible and uncertain of one's own personality", or "listening and watching everything that is offered; listening and watching the same on all channels or in all programs". Conformism is typical of any society, pre-industrial or post-industrial, totalitarian or post-totalitarian, and even any audience, including students. However, conformism affects not only the development of society, but also the development of mass media, in particular, broadcasting. The latter cannot exist on the basis of indifference and passivity. In fact, television and radio as business require activity, movement and development. Only in this case can one count on success. "Conformists" embody the model of passive and indifferent students. They cannot determine for sure whether or not they are going to work in broadcasting, because they do not know exactly if they are skilful enough. Therefore, it doesn't matter how they watch television or listen to the radio (via satellite or online), because they are not very interested in TV and radio broadcasting.

"Conformists" perceive television and radio at the consumer level, in other words, how easy and affordable "it can be used". Consumerism is one of the characteristics of so-called "Soviet people" which cannot be classified as negative or positive. It is deeply rooted in consciousness and plays the main role in the perception of reality (Kamensky V., 1999). It may sound strange enough but it is still evident today in the student milieu of the post-Soviet countries. Consumers evaluate the 
sociocultural progress of society by standard consumer categories. Broadcasting works for the consumer, reflecting the model of society. The Ukrainian media market is not an exception. Ukrainian TV and radio companies broadcast a mutation of old consumer clichés using new technologies and communication methods.

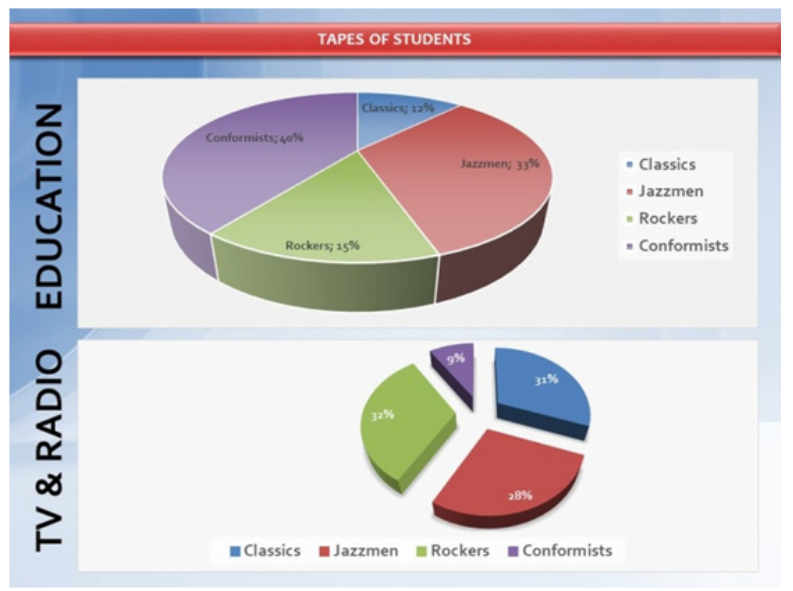

As a result, the study identified four psychotypes of students differentiated by their attitude to modern broadcasting. The scheme gives an idea of the percentage of students studying in the speciality "Journalism and Social Communications" in the Institute of Journalism, Taras Shevchenko National University of Kyiv, and specializing in television and radio broadcasting. These are the psychotypes of students who, after graduation, go to work on television and radio.

\section{Conclusion and Future Scope}

The results of the study revealed a systematic problem in preparing journalists for television and radio broadcasting, in particular, at the stage of selecting a professional specialization by students, and while studying in specialization groups. The majority of the interviewed students associate television and radio only with terrestrial (digital), satellite or cable broadasting (linear television or radio) without considering online podcasting or online streaming of TV and radio companies, including social networks, as a new scope of modern broadcasting. Why is the problem becoming systematic? This is the opinion of many students, not only in Ukraine, but also in other media societies (Pew Research Center, 2017), which, having access to the broadband Internet, receive information about television and radio broadcasting on a regular basis only through online technologies. To draw a conclusion we must admit the following:

1. Journalism schools that teach the basics of TV and radio broadcasting should consider this problem and know how to solve it, using, for example, a technological approach, offered by the authors of the article, to the psychotypes of the student audience. Consequently, student groups that choose television or radio broadcasting as a speciality usually consist of the representatives of each of the four psychotypes listed.

2. Theoretically only the representatives of the "Classics" type cannot definitively form the groups of TV and radio specialization, but the constant presence of such students in these groups is a sign of perspective and stability. They try to reasonably approach the choice of the future profession, since any information is perceived not by feelings, but by mind. There are a lot of them working for TV and radio companies, but this type does not occupy the leading position in the ratings of TV and radio programs. For "Classics", it is necessary to 
develop special tasks that will require the involvement of analytic skills and, at the same time, use a variety of creative assignments, which will positively influence the creative thinking and balance the pragmatic and emotional components during the creation of educational television and radio projects.

3. "Jazzmen" sensibly perceive the surrounding reality, because, as already mentioned, the emotionality of this psychotype of students is very high, so the number of "Jazzmen" among student journalists and later in professional communities is sufficient. Such students should always be supported. They prepare television programs on the instinct level, often finding polar positions (positive and negative, good and bad). They critically evaluate their work, but they can easily succeed in it, because no television or radio company can manage without an emotional component. The psychotypes of "Classics" and "Jazzmen" are somewhat similar, because they are based on the categorical perception: "everything that was created earlier is better than what is happening today" ("Classics") and "everything that is happening today, is an imitation of what was created earlier" ("Jazzmen").

4. Psychotypes of "Rockers" and "Conformists" are completely opposite, both in student groups and in the professional environment. And this discrepancy lies precisely in the context of the "background" and "purposeful" perception of the profession during studying and practising, as well as in their professional activity in the media.

5. Students should be explained that the advent of new media technologies on the TV and radio market does not imply the repudiation of previous technological advances that television and radio have successfully used before and still continue to use. It has always been so, and the history of broadcasting has numerous examples of tolerant coexistence of different technologies and successful combination of different standards on the same media platforms. Today the smartphone screen is only the third television and visualized radio screen after a smart TV and a computer. Moreover, from the history of TV broadcasting, we know that the promising TV and radio business starts with the competition among content producers. And only then does the quality content seek the right target audience, is placed on competitive distribution channels, and attract competitive technologies of distribution.

These are the basic concepts and starting arguments that should be taken into consideration when preparing TV and radio journalists for their future profession.

\section{References}

Goian O., Goian V., 2013. Student Television and Radio in Ukraine: Forming a New Media Market, Collection of Social Communications in the World, K., pp. 68-72.

McCormick R., 1985. Students'Views on Study at the Radio and Television Universities in China: an investigation in one local centre, British Journal of Educational Technology, Wiley Online Library, Volume16, Issue2, pp. 84-100;

Damratoski K. J., Field A. R., Mizell K. N., Budden M. C., 2011. An Investigation Into Alternative Television Viewership Habits Of College Students, The Journal of Applied Business Research, Volume 27, Number 1, pp. 69-76;

Morris A., 2016. Student Radio Dramas, Writing in Education, Issue Number 68, pp. 63-67.

According to the legislation of Ukraine: as of 01.01.2020 there are three types of media in Ukraine: print media, television and radio broadcasting. Available:

Adorno T. V., 1998. Favorites: Sociology of Music, M, St. Petersburg, University Book, 445 p.

Roshchin S.K., 1989. Psychology and journalism, Moskow, Science, P.15.

Sukhareva V., 2003. On the other side of the ether, Domestic notes, Vol.4.

Audiomania, 2018. How intellect and musical preferences are connected: theories andresearch. Availible: https://sudonull.com/post/53047-How-intellect-and-musical-preferences-are-connected-theories-andresearch-Audiomania-company-blog

Lyzanchuk V.V., 1997. TV and Radio Journalism: History, Theory, Practice, Looking to the Future / Collection of scientific and methodological works, Lviv, Ed. Department of Lviv. uni, P. 34.

Tkachuk T, 2004. Conformism and nonconformism, 2004. Availible: https://www.svoboda.org/a/24201174.html 
Karpenko V., 2002. Fundamentals of Professional Communication, Kyiv, Nora-print, P. 82.

Dictionary of Foreign Languages, 20oo. Compiled by: S.M. Morozov, L.M. Shkaraput, Kyiv, Sciences Opinion, P. 295.

Kamensky V., 1999. The strange community of people - the "Soviet people - and its listening attention", TV and radio courier, Vol. 1., P. 69.

Pew Research Center, 2017. About 6 in 10 young adults in U.S. primarily use online streaming to watch TV. Availible: https://www.pewresearch.org/fact-tank/2017/og/13/about-6-in-10-young-adults-in-u-s-primarilyuse-online-streaming-to-watch-tv/ 